\title{
CONTRAST IN CLAY MINERALOGY AND THEIR EFFECT ON RESERVOIR PROPERTIES IN SANDSTONE FORMATIONS
}

\author{
Wolela Ahmed* \\ Petroleum Operations Department, Ministry of Mines and Energy, P.O. Box 486, Kotebe \\ Branch, Addis Ababa, Ethiopia
}

(Received October 4, 2006; revised July 22, 2007)

\begin{abstract}
Adigrat sandstone formation in the Blue Nile Basin is dominated by quartz arenite and subarkosic arenite, and cemented by carbonate, clay minerals and quartz overgrowths. Clay minerals in the Adigrat sandstone formation are dominated by kaolinite, illite and chlorite. Illite is the common grain-coating clay mineral. The common pore-filling minerals are kaolinite, illite and chlorite. The formation reaches a depth of 3 $\mathrm{km}$, which facilitated the change of kaolinite to illite. Clay minerals are the major reducer of porosity and permeability in the Adigrat sandstone formation.

The Permo-Triassic sandstones in the Ulster Basin were deposited in NE-SW trending fault-bounded asymmetrical graben. The Permo-Triassic sandstones reaches a burial depth of $1 / 2 \mathrm{~km}$ in the marginal areas and $4.5 \mathrm{~km}$ in the basin center. The basin underwent multiple episodes of uplift and erosion in the Upper Jurassic, and Mid-Cretaceous, and uplift and inversion in the Upper Tertiary. The difference of the clay mineralogy in the Permo-Triassic in the Ulster Basin depends upon the depositional environments, source area geology and burial history of the basin. Illite-smectite is grain coating, whereas smectite, illite-smectite, smectite-chlorite, chlorite, illite and kaolinite are the common pore-filling clay minerals in the Permo-Triassic sandstones in the Ulster Basin. Clay minerals reduced the porosity and permeability of the Permo-Triassic sandstones.
\end{abstract}

KEY WORDS: Adigrat sandstone, Authigenic mineralization, Clay minerals, Diagenesis, Permo-Triassic sandstones, Reservoir characteristics

\section{INTRODUCTION}

The major factors which control diagenesis of sandstones and other clastic sediments include: temperature, pore water chemistry, fluid flow, mineralogical partitioning, depositional environments, tectonic setting, burial time of uplift, geothermal gradient and subsurface pressure $[1,2]$. The Adigrat sandstone formation, Blue Nile Basin, Ethiopia and the Permo-Triassic sandstones, Ulster Basin, Northern Ireland are considered for case studies to understand clay mineralogy impact on porosity permeability and other reservoir characteristics. These sandstone formations are potential hydrocarbon reservoir in these basins. Hence, it is important to evaluate thoroughly the types of clay minerals in these sandstones.

The most common pore-filling cements in the Adigrat sandstone formation include: carbonates (calcite and dolomite), silica, hematite, and clay minerals (kaolinite, illite and chlorite) [3]. The abundance of clay minerals in the Adigrat sandstone formation in decreasing order includes: kaolinite $>$ illite $>$ chlorite. The porosity value in the Adigrat sandstone formation ranges from 0.1 (in tightly compacted and clay cemented areas) to $20.4 \%$ (in areas where secondary porosity generated by dissolution of carbonate).

The Permo-Triassic sandstones in the Ulster Basin had a complex diagenetic history. The most common paragenetic pore-filling minerals in these sandstones are mechanically infiltrated clay, grain coating illite-smectite/hematite, concretionary (calcite, dolomite and anhydrite), feldspar overgrowths, quartz overgrowths, carbonate cements (dolomite, ferroan dolomite, calcite and ferroan calcite), kaolinite, illite, illite-smectite, smectite-chlorite and hematite $[3,4]$. Authigenic clay minerals abundance in the Permo-Triassic sandstones in decreasing order includes: illite-smectite $>$ smectite $>$ smectite-chlorite $>$ illite $>$ kaolinite $>$ chlorite.

${ }^{*}$ Corresponding author. E-mail: Wolela_am@yahoo.com 
Intergranular porosities in the Permo-Triassic sandstones are reduced by mechanical compaction, clay minerals, carbonates and feldspar overgrowths. In the later-stages of diagenesis, dissolution of carbonate cements and unstable grains facilitated secondary porosity generation. The porosity ranges from $0.1 \%$ (in tightly compacted and clay cemented areas) to $27 \%$ (in areas porosity generated by the dissolution of carbonate cements). In some places, the reservoir quality of the basin is highly affected by mechanically infiltrated clays, grain-coating and pore-filling clay minerals. The abundance of mechanically infiltrated clays inhibited carbonate authigenesis, feldspar overgrowths and the generation of secondary porosity.

The carbonates and silica cemented sandstones are more porous and permeable than clay cemented sandstones. Dissolution improved the reservoir characteristics in carbonate cemented sandstones, whereas clay mineral cemented sandstones do not have the chance to improve reservoir characteristics at the time of the percolation of acidic pore waters during diagenesis. Reservoir characteristics of the studied sandstones are highly affected by clay minerals.

$\mathrm{X}$-ray diffraction (XRD) provides information on the type of clay minerals. However, these clay minerals indicated by XRD peaks possibly derived from (i) mechanically infiltrated clay originating from percolation of mud-rich waters or illuviation of clay cutans, (ii) pedogenic mud aggregates, (iii) transformational clay, i.e. changing of mechanically infiltrated clay and pedogenic mud aggregates to authigenic clay, (iv) alteration of K-feldspar and ferromagnesian minerals to clay minerals, and (v) neoformed clay directly precipitated from pore water. Differentiation of the type of clay minerals is vital to understand the porosity, permeability and other reservoir characteristics of sandstones.

Other than XRD studies, in order to differentiate different types of clay minerals detail study needed to be carried out using scanning electron microscope (SEM). Scanning electron microscopy provides wide range of information about the morphology, mineral composition, distribution and paragenesis of the neoformed authigenic clay minerals, mechanically infiltrated clays, transformational clays and pedogenic mud aggregates. Therefore, it is vital in petroleum exploration to differentiate clay cemented areas from carbonate, hematite and silica cemented areas. The study conducted on these sandstones to understand the contrast and similarity of the clay mineralogy, and their effect on the porosity, permeability and other reservoir characteristics. The Triassic-Liassic Adigrat sandstone formation and the Permo-Triassic sandstones were deposited intercratonic rift basins, and are the potential hydrocarbon reservoir rocks in these basins. Only scanty information is available regarding the clay mineralogy and their effect on these sandstones reservoirs. This paper presents detailed account of the clay mineralogy of the two sandstone formations.

\section{BACKGROUND GEOLOGY OF THE BLUE NILE BASIN, ETHIOPIA}

The break-up of the Gondwanaland in the Permo-Triassic produced cratonic rift basins around the border of the megacontinent. In East Africa, these basins were developed by extensional and transtensional movements [3, 5]. The Blue Nile Basin is one of the failed arms of the Karroo Rift system [6]. Precambrian basement rocks, Karroo sediments, Adigrat sandstone formation, Middle Hamanlei (Gohatsion) limestone formation, Upper Hamanlei (Antalo) limestone formation, Mugher mudstone formation, Debre Libanose sandstone formations and Tertiary volcanics are dominant rocks types in the basin. The basin is floored by Precambrian basement and contains several successions of Palaeozoic and Mesozoic sediments and volcanics (Figures 1 and 2).

The Precambrian basement rocks are granite, grano-diorite gneisses, quartzite and metavolcanics. Sedimentation was commenced with the deposition of $450 \mathrm{~m}$ thick continental clastic Karroo sediments. The Palaeozoic Karroo sediments are unconformably overlain by up to 
$850 \mathrm{~m}$ thick alluvial fan and fluviatile-dominated Adigrat sandstone formation. The formation consists of mudstone, thinly laminated siltstone, fine-grained cross-bedded sandstone and coarse to medium-grained sandstone, massive to cross-bedded gravely sandstone and massive to crudely bedded gravely conglomerate facies [3]. A $30 \mathrm{~m}$ thick transitional facies was developed between the continental Adigrat sandstone formation and marine-dominated the Middle Hamanlei (Gohatsion) limestone formation.

In the Early Jurassic, the Horn of Africa was marked by the major transgression of the sea initiated by thermal subsidence [3, 7, 8]. The transgression of the sea is marked by the deposition of the $350 \mathrm{~m}$ thick Middle Hamanlei (Gohatsion) limestone formation, which is composed of dolostone, gypsum, mudstone, marl and shale [3, 9-11]. The Upper Hamanlei limestone formation conformably overlies on the Middle Hamanlei limestone formation. Marly limestones, skeletal packstone-wackstone and oolitic-skeletal packstone dominated the over 720 $m$ thick (bottom unexposed) Upper Hamanlei limestone formation [3, 10].

The Upper Hamanlei limestone formation vertically passes up into a $15 \mathrm{~m}$ thick transitional facies, and overlain by the $280 \mathrm{~m}$ thick Muger mudstone formation. The Muger mudstone formation is conformably overlain by $310 \mathrm{~m}$ thick Debre Libanose sandstone formation $[3,10]$. The Debre Libanose sandstone formation is unconformably overlain by Trap volcanics. A large portion of the Paleozoic and Mesozoic sediments in the Blue Nile Basin are buried under thick Tertiary volcanics.

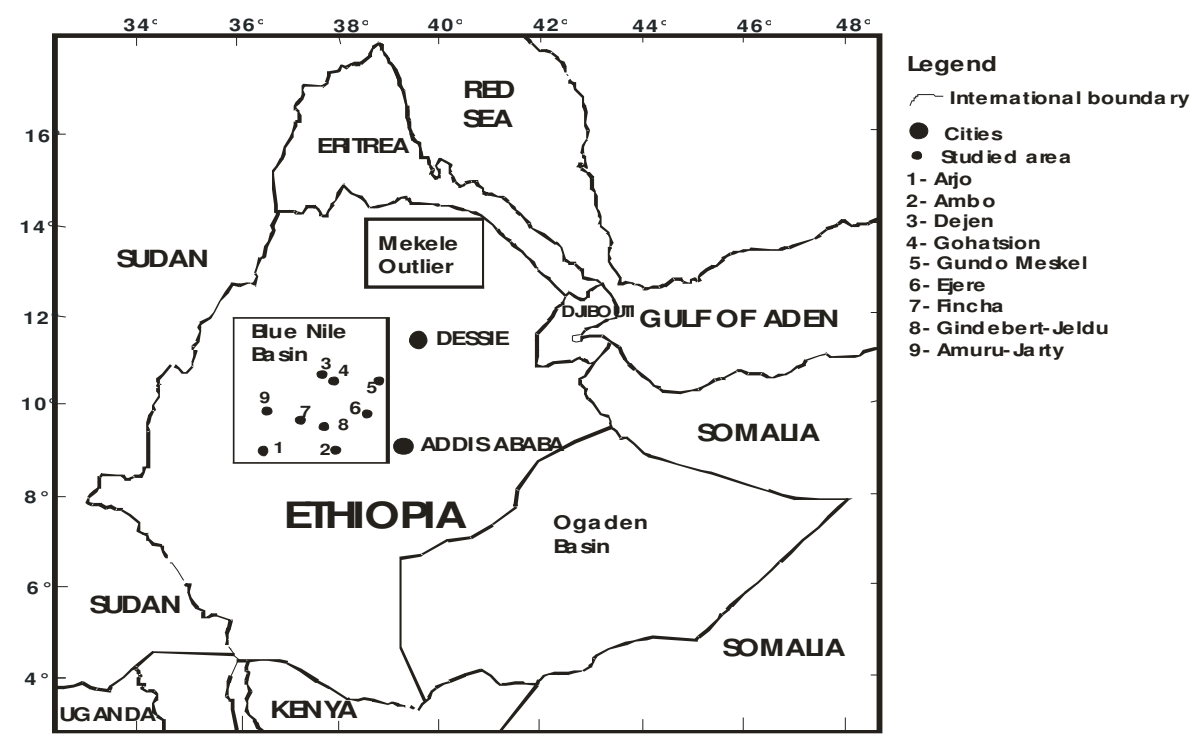

Figure 1. Geological and location map of studied areas, Blue Nile Basin. 


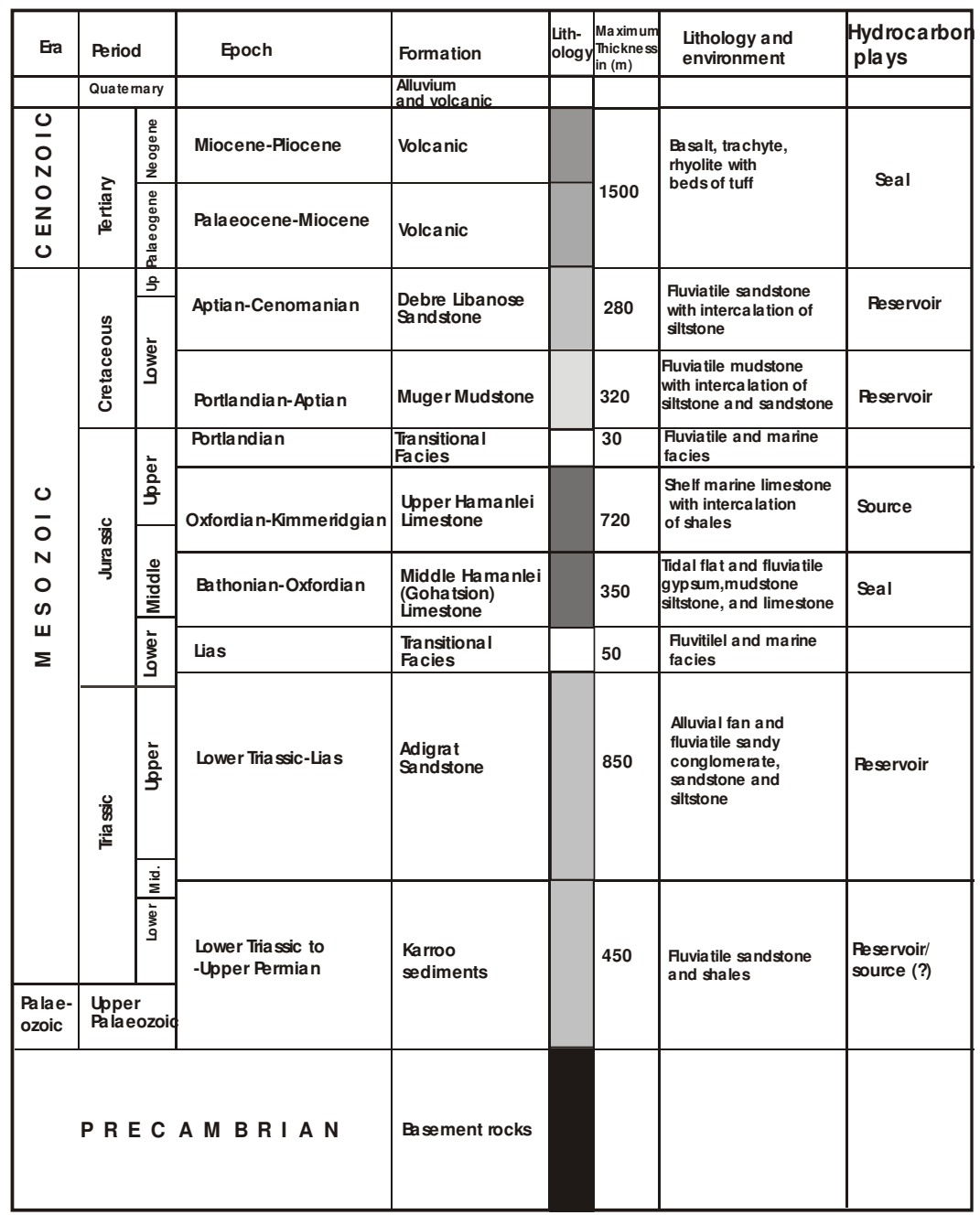

Figure 2. Chrono, litho-stratigraphic section of the Blue Nile Basin.

\section{EXPERIMENTAL}

Sandstone samples were collected from different sandstone formations in the Blue Nile and Ulster Basins. Samples were cleaned in ultrasonic bath to remove the effect of recent weathering. The sandstone samples were impregnated with blue resin (blue-dyed araldite) to highlight porosity. Resin-impregnated thin sections were examined using petrographic microscope, and their model composition evaluated by point counting (500 points per thin section). Counts were made by using the microscope's medium magnification power (field of view $=1.8 \mathrm{~mm}$ ). 
Gold-coated chip samples were examined under a JEOL 6400 scanning electron microscope (Queen's University of Belfast) equipped with energy dispersive X-ray analysis (EDX) system with accelerating voltage 10 to $15 \mathrm{kV}$, to study the morphology, mineral composition, distribution and paragenesis of the authigenic minerals and pore throat geometry.

Quantitative analyses were carried out on polished samples and thin sections using a JEOL 733 superprobe (Queen's University of Belfast) with an accelerating voltage of $15 \mathrm{kV}$, probe current of $1 \times 10^{-8} \mathrm{~A}$ and spot size $1 \mu \mathrm{m}$ to identify mineral composition, mineral transformation and zoning in cementing minerals. A ZAF calculation software programme was used to calculate weight percentage of oxides in each analysis.

About $10 \mathrm{~g}$ of rock sample was crushed and ground with a ceramic mortar and pestle. The powder was washed in a $500 \mathrm{~mL}$ beaker where deionized water was added. Further disaggregation was accomplished by submerging the beaker into ultrasonic bath for $5 \mathrm{~min}$. The less-than-two micron fraction was separated by gravity settling in the beaker at $20{ }^{\circ} \mathrm{C}$. After 3 hours of setting, the top $5 \mathrm{~cm}$ of the beaker was transferred by pipeting to sealable container. When significant flocculation occurred the sample was treated with sodium hexametaphosphate and agitated in ultrasonic bath for $5 \mathrm{~min}$. Powder sample were gently presses into aluminium holder and run on a X-ray diffractometer (XRD). XRD patterns were made using Ni-filtered $\mathrm{Cu} \alpha$ radiation at a scanning rate of $1 \% \mathrm{~min}$ in $2 \theta$.

\section{RESULTS}

Diagenesis of the Adigrat sandstone formation. The Adigrat sandstone formation is a coarse-tofine-grained, sub-angular to rounded, moderately sorted sandstone. Quartz is the dominant framework grain in the studied sandstones. The feldspar content is consistently low. The average mode of 65 sandstone samples from the Adigrat sandstone formation revealed $\mathrm{Q}_{92 \cdot 1} \mathrm{~F}_{7.5} \mathrm{~L}_{0.9}$. The Adigrat sandstone formation falls within the domain of fine to coarse-grained quartz arenites and sub-arkosic arenites [12], and are cemented by clays, hematite, carbonates and silica minerals (Table 1).

Table 1. Framework grains, cementing minerals and porosity of the Adigrat sandstone formation, Blue Nile Basin.

\begin{tabular}{|c|c|c|c|c|c|c|c|c|c|c|c|c|c|}
\hline \multirow[b]{2}{*}{ Locality } & \multirow{2}{*}{$\begin{array}{c}\text { Sample } \\
\text { No }\end{array}$} & \multirow{2}{*}{$\begin{array}{l}\text { Cement } \\
\text { type }\end{array}$} & \multicolumn{4}{|c|}{ Framework grains (\%) } & \multirow[b]{2}{*}{$\begin{array}{c}\text { Opa- } \\
\text { que }\end{array}$} & \multicolumn{5}{|c|}{ Cementing minerals (\%) } & \multirow[b]{2}{*}{$\begin{array}{c}\begin{array}{c}\text { Poro- } \\
\text { sity }\end{array} \\
\end{array}$} \\
\hline & & & Quartz & \begin{tabular}{|c|} 
Feld- \\
spar
\end{tabular} & $\begin{array}{c}\text { Rock } \\
\text { fragment }\end{array}$ & Mica & & Clay & $\begin{array}{c}\text { Calci- } \\
\text { te }\end{array}$ & \begin{tabular}{|c|}
$\begin{array}{c}\text { Dolo- } \\
\text { mite }\end{array}$ \\
\end{tabular} & \begin{tabular}{|c} 
Sili- \\
ca
\end{tabular} & $\begin{array}{c}\text { Hema- } \\
\text { tite }\end{array}$ & \\
\hline Dejen & BND-1 & \multirow{2}{*}{ Hematite } & 76 & & & & 1.2 & & & & & 13.4 & 7.6 \\
\hline Jimma & $\mathrm{BNJ}-2$ & & 73 & 2 & 1 & 6 & 1 & & & & & 12 & 4 \\
\hline Dejen & BND-2 & \multirow{4}{*}{ Clay } & 73 & 1 & 0.8 & & 4 & 14.2 & 0.5 & & & & 7.5 \\
\hline Jimma & BNJ-1 & & 72 & 2 & & & 4 & 10 & 1 & & & 4 & 7.5 \\
\hline Dejen & BND-3 & & 70.6 & 16.2 & 2.2 & 2.8 & 1.6 & 5.4 & & & & & \\
\hline Ambo & BNA-1 & & 46 & 25 & 3 & 2 & 1 & 13 & & & & & 7 \\
\hline Dejen & BND-5 & \multirow{4}{*}{ Carbonate } & 58.5 & 9 & 2.5 & & & & 22.5 & & & & 8 \\
\hline Dejen & BND-6 & & 58 & 10 & 3 & 1 & & & 28 & & & 6 & 3.6 \\
\hline Dejen & BND-7 & & 74.4 & 6.2 & 0.2 & 0.6 & & & 18.4 & 2.4 & & & 6.8 \\
\hline Arjo & BNAR-1 & & 67.8 & 0.2 & & 0.6 & & & 21.4 & & & & 10 \\
\hline Dejen & BND-8 & \multirow[b]{2}{*}{ Silica } & 70.2 & 2 & & 0.6 & 2 & & & & 6.2 & 4 & 15 \\
\hline Dejen & BND-9 & & 71.5 & 8.5 & 1.5 & & & & & & 8 & & 11 \\
\hline
\end{tabular}


The Adigrat sandstone formation had a complex diagenetic history. The authigenic minerals reflect changes in the pore water chemistry. The relative sequence of the diagenetic events is shown in Figure 3. Based on the results of the petrographic microscopy, electron microprobe and scanning, electron microscopy the paragenetic sequence include: (1) early concretionary calcite, (2) grain dissolution, (3) hematite and/or illite grain coating, (4) quartz overgrowths, (5) feldspar overgrowths, (6) calcite cementation, (7) dolomite cementation, (8) mechanical compaction, (9) cement dissolution, (10) kaolinite precipitation, (11) euhedral quartz crystals, (12) hematite precipitation, (13) illite precipitation and (14) chlorite precipitation [3].

Minor amounts of barite cement were identified by microprobe analysis. The paragenetic context of barite is not clear. Barite is possibly derived from either alteration of plagioclase and K-feldspar and/or from the overlying gypsum and limestone-rich Middle Hamanlei limestone formation.

A.

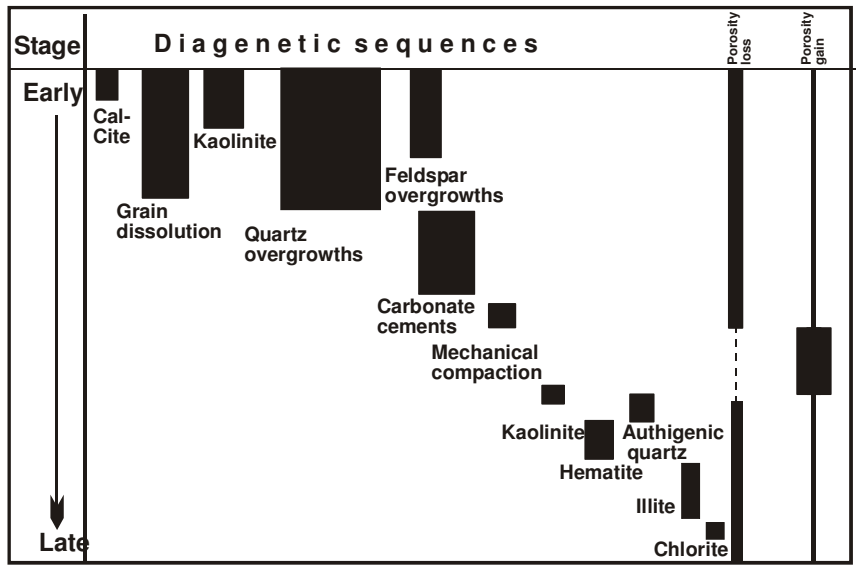

B.

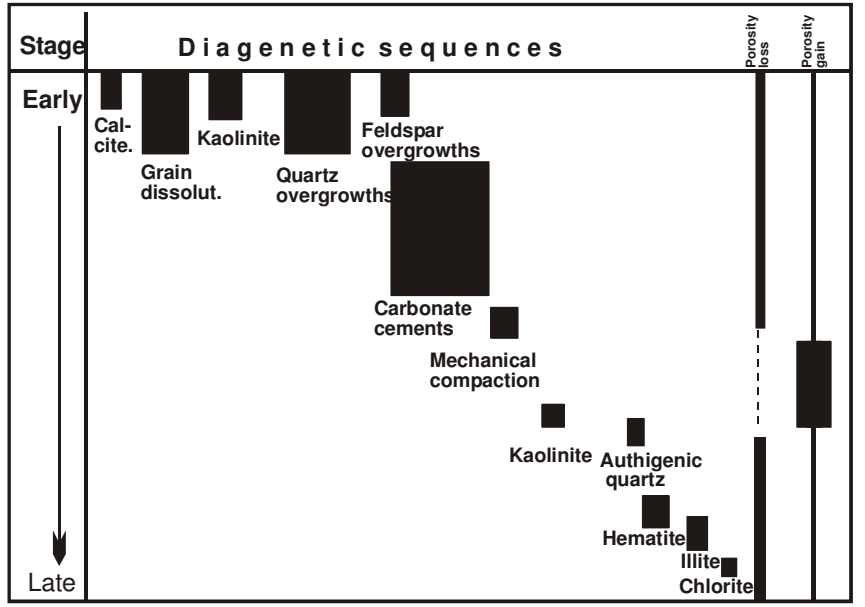

Figure 3. Diagenetic sequences of the Adigrat sandstone formation. 
It is possible to suggest a model of involving pore water chemistry to explain the following sequences from early to late diagenesis: (1) an influx of meteoric water and reaction with carbon dioxide facilitated acidic environment to leach out unstable grains, (2) $\mathrm{pH}$ increase and precipitation of grain-coating illite followed by quartz overgrowths, feldspar overgrowths, calcite and dolomite cementation under alkaline conditions, (3) carbon dioxide released from mature source rocks and clay minerals transformation causing an activated acidic environment to leach out carbonate cements and unstable grains to generate secondary porosity, and (4) reaction between acidic pore water and carbonate cements increased the $\mathrm{pH}$ value and precipitation of pore-filling kaolinite, illite, hematite and chlorite.

The clay minerals in the Adigrat sandstone formation are described below.

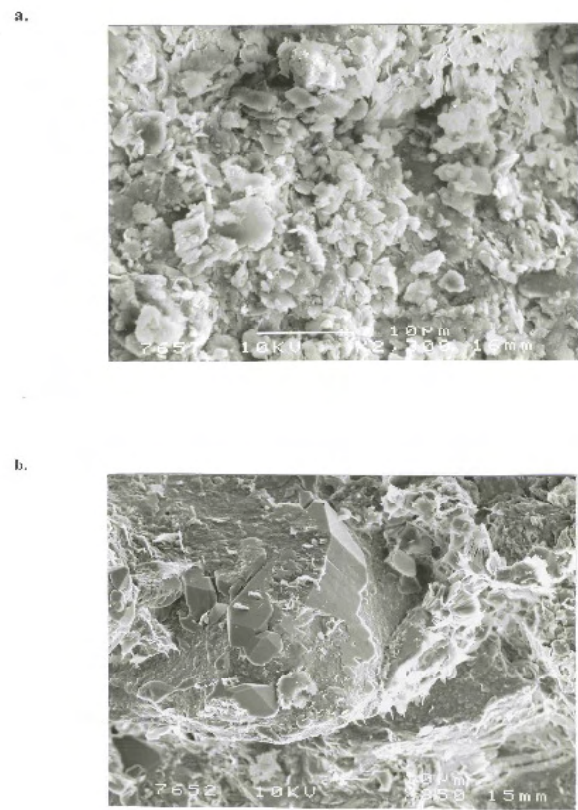

Figure 4. SEM photomicrograph showing (a) infiltrated clay, Adigrat sandstone formation (scale bar 10 micron) (b) grain-coating illite, Adigrat sandstone formation, (scale bar 10 micron).

Mechanically infiltrated clays. Petrographic microscopy and SEM studies confirmed the presence of mechanically infiltrated clay (Figure 4a). Mechanically infiltrated clay is one of the earliest clay minerals. Brown coloured infiltrated clays partially fill pore spaces. The infiltrated clays account up to $0.5 \%$. They occur together with opaque minerals, and have poorly crystalline appearances indicating their detrital origin. They commonly choke pore-throats together with the opaque minerals.

Grain-coating clay minerals. Grain-coating illite is considered to be the earliest authigenic mineral (Figure 4b). It is well-developed around detrital grains as partial or complete coatings and show high birefringence around the grains. Grain-coating illite precipitated before quartz overgrowths. Where the clay rim is thin, discontinuous nucleation of quartz overgrowths are exhibited. However, in some instances the clay rims are thick enough to prevent quartz and 
feldspar overgrowths. Grain coating clays account about $1 \%$. Illite precipitation reduced primary porosity.

\section{Pore-filling clay minerals}

(a) Kaolinite. Volumetrically, kaolinite is the most abundant type of authigenic clay mineral in the Adigrat sandstone formation and accounts up to $10 \%$. Humid climate might have favoured the dissolution of feldspar in the source terrains. Chemical instability of the detrital minerals with respect to circulating acidic pore waters led to the dissolution of feldspars. Precipitation of kaolinite took as the pore water supersaturated with silicon and aluminium ions. It occurs as pore-filling cement and forms dark brown patches in thin section. Two morphotypes (pseudohexagonal and booklets) of kaolinite were identified by SEM examination. The pseudohexagonal kaolinite plates (Figure 5a) are randomly distributed and they are $1 \mu \mathrm{m}$ to 5 $\mu \mathrm{m}$ across and up to $8 \mu \mathrm{m}$ in length. Kaolinite forms well developed euhedral, blocky crystals and clusters of booklet-like grains (Figure 5b), that partially or completely filled primary and secondary pore spaces. The pseudohexagonal platy kaolinite precipitated on authigenic quartz crystals. It is not possible to differentiate the cement time sequence of booklet kaolinite and pseudohexagonal kaolinite. The authigenic kaolinite crystals are best developed in areas where authigenic feldspar is poorly developed. XRD results also confirmed the presence of kaolinite and chlorite (Figure 6).

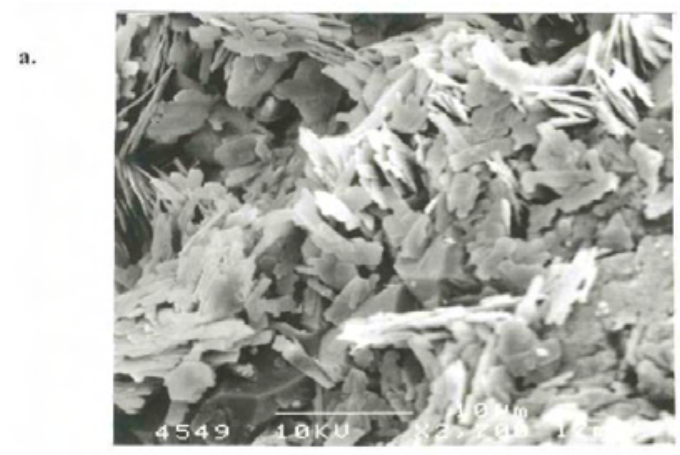

b.

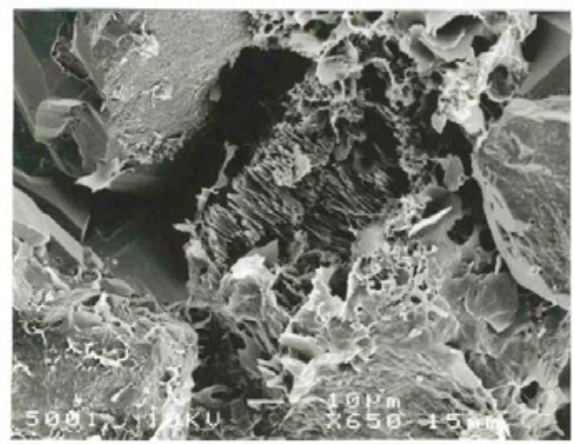

Figure 5. SEM photomicrograph showing (a) pseudohexagonal kaolinite, Adigrat sandstone formation (scale bar 10 micron) (b) booklet kaolinite, Adigrat sandstone formation (scale bar 10 micron).

Bull. Chem. Soc. Ethiop. 2008, 22(1) 
(b) Illite. Volumetrically, illite is the second authigenic clay mineral, and constitutes about 2 $\%$. It occurs as poor to well-crystalized lath-like blades, and fiber-like morphology (Figure $5 b)$. Illite is precipitated in primary and secondary pore spaces. In some places, illite fibres and plates are associated with kaolinite, indicating illitization of kaolinite (Figure 5b). Illite is well developed where feldspar overgrowths is less developed. It is a typical feature of coarse to medium-grained sandstones.

(c) Chlorite. SEM studies showed the presence of minor amounts of chlorite minerals in the Adigrat sandstone formation. XRD results also confirmed the presence of chlorite (Figure 6). Chlorite occurs in a rosette morphotype (Figure 7a).

\section{DISCUSSION}

The coarse to medium-grained sandstone is predominantly a light grey colour in the lower part, and vertically passes into reddish brown to red sediments and finally into carbonaceous sediments. The presence of a light grey and reddish brown colour indicates climatic variation at the time of deposition from a sub-tropical humid climate to a semi-arid to arid climates. The passage from reddish brown to lacustrine dark grey sediments indicates sub-tropical humid climatic conditions. The grey to dark grey colour indicates a reducing environment, possibly shallow lakes in the flood plain. At early-stage diagenesis, the climate was dominated by arid to semi-arid climate for the development of grain-coating illite.

Authigenesis of grain-coating clay mineral. The ions released from the dissolution of unstable minerals are the controlling factor for the type of clay minerals to be precipitated. The Precambrian basement rocks are the possible source for the authigenesis of different types of clay minerals. The dissolution of unstable grains (feldspar and ferromagnesian minerals) provided the necessary ions for the precipitation of illite and hematite. The presence of heavy minerals and opaque minerals are clues to the former presence of ferromagnesian minerals. It is noted by some workers that unstable framework grains leached by meteoric water at shallow burial depth to provide different types of ions for the precipitation of different minerals in the diagenetic environment [13, 14]. In semi-arid and arid areas under an oxidizing environment iron is present as ferric oxides and enters into the crystal lattice of the clay or makes coatings around the clay [15]. Grain-coating illite was the first phase to be precipitated when the activity of $\mathrm{K}^{+}$and $\mathrm{H}_{4} \mathrm{SiO}_{4}$ was sufficiently high [16]. The presence of grain-coating illite and hematite indicates simultaneous precipitation.

Authigenesis of late-stage pore-filling clay minerals. The reaction between rock forming minerals and the acidic pore water increased the $\mathrm{pH}$. The $\mathrm{pH}$ value increased through dissolution of carbonate cements by acidic pore water, and thereby facilitated precipitation of kaolinite in the pore spaces from silicon and aluminium supersaturated pore water [17]. Kaolinite can crystallize during both shallow and deep burial [18]. Kaolinizing fluid can result from (1) $\mathrm{CO}_{2}$ evolution during shale diagenesis and compaction, and (2) $\mathrm{CO}_{2}$ evolution during the diagenesis of organic matter [19]. The presence of abundant of kaolinite in the Adigrat sandstone formation possibly indicated large amount of feldspar before dissolution. Generally, kaolinite is confined to the purest sandstones where its growth was not inhibited by detrital clays [20]. Kaolinite abundantly precipitated in the coarse to medium-grained sandstone facies in the Adigrat sandstone formation. Booklets of kaolinite in the Adigrat sandstone formation precipitated directly from the pore water, whilst the pseudohexagonal platy kaolinite is an alteration product from feldspar and/or directly precipitated from the pore water [21]. Kaolinization of feldspar 
produces silica corresponding to $40 \%$ of the altered feldspar, which may precipitate as quartz cement [13].

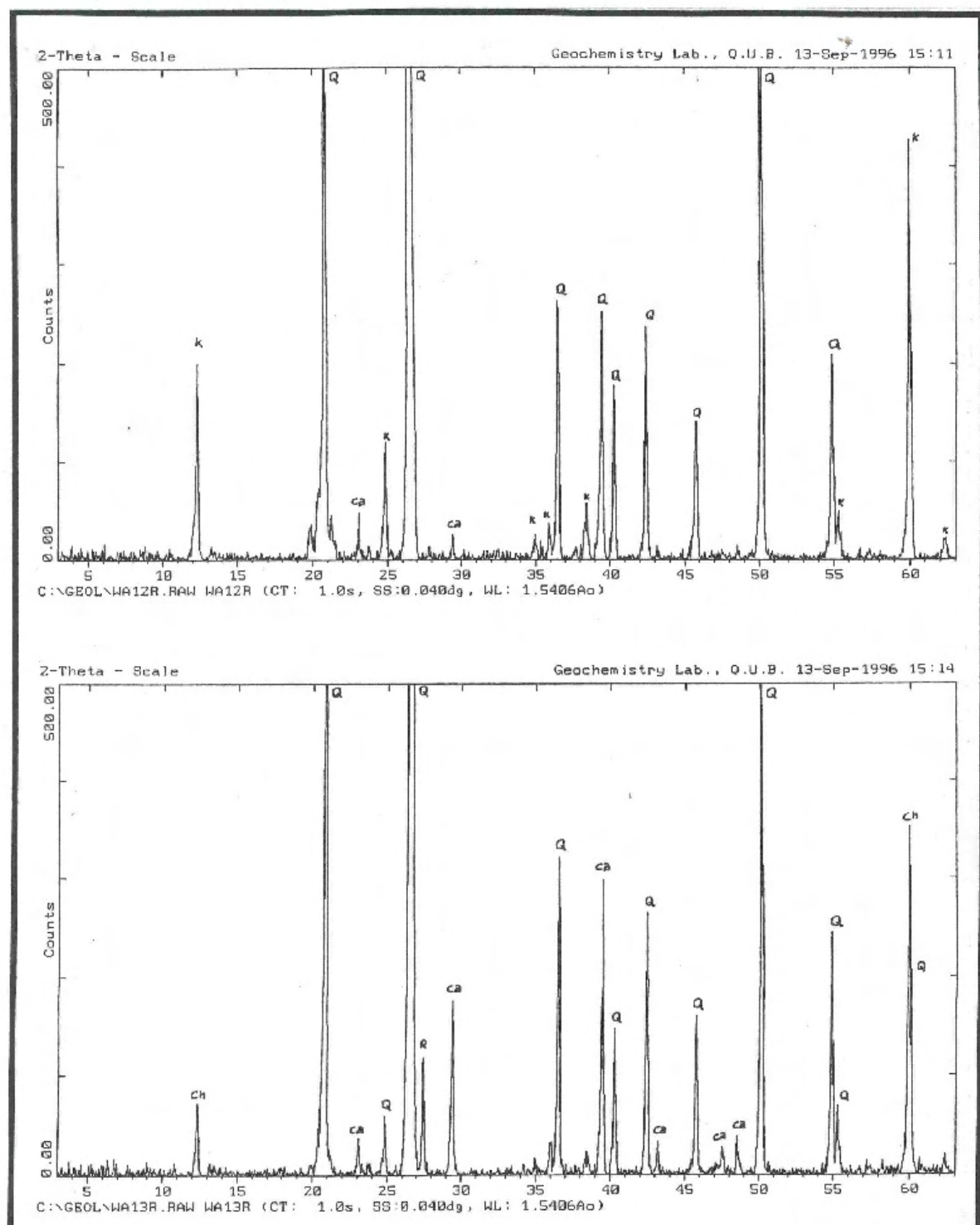

Key: $\mathrm{Q}=$ quartz, $\mathrm{Ca}=$ calcite, $\mathrm{Ch}=$ chlorite $\mathrm{R}=$ rutile, $\mathrm{K}=$ kaolinite,

Figure 6. XRD results of the Adigrat sandstone formation.

Bull. Chem. Soc. Ethiop. 2008, 22(1) 
Illitization of kaolinite indicates an increase in burial depth and crystallinity as the paleotemperature increased. The transformation from kaolinite to illite might have been favoured by potassium ions from the dissolution of K-feldspar and its overgrowths. Kaolinite can be altered to illite and/or chlorite when the pore water changes from acidic to alkaline condition. Illitization needs $\mathrm{K}^{+}$ions and chloritization need $\mathrm{Mg}^{2+}$ and $\mathrm{Fe}^{2+3+}$ ions. Illitization and chloritization indicate an increase in burial depth and crystallinity.

Effect of clay minerals on porosity and reservoir characteristics. The primary and secondary porosity in the Adigrat sandstone formation was also reduced by the precipitation of kaolinite, chlorite and illite (Figures $4 \mathrm{a}$ and b, 5a and $\mathrm{b}$ and $7 \mathrm{a}$ ). The clay cemented area reaches up to 7.5 $\%$ (Table 1). Kaolinite composed of booklet crystals stacked several microns in diameter reduce porosity but not permeability $[22,23]$. Kaolinite clearly reduces porosity, but still exhibits an effective microporosity because permeability between pores is not so restricted [24]. Kaolinite has a very marked effect on the porosity, and the limited microporosity between kaolinite crystals is either not filled with oil or oil can not be produced from such pores [25].

Though volumetrically less abundant, the late-stage illite with platy and hairy terminations reduces the permeability, but porosity is not so restricted. The permeability of illite-cemented sandstone does not exceed $1 \mathrm{mD}$, even in samples with porosities above $10 \%$ [26].
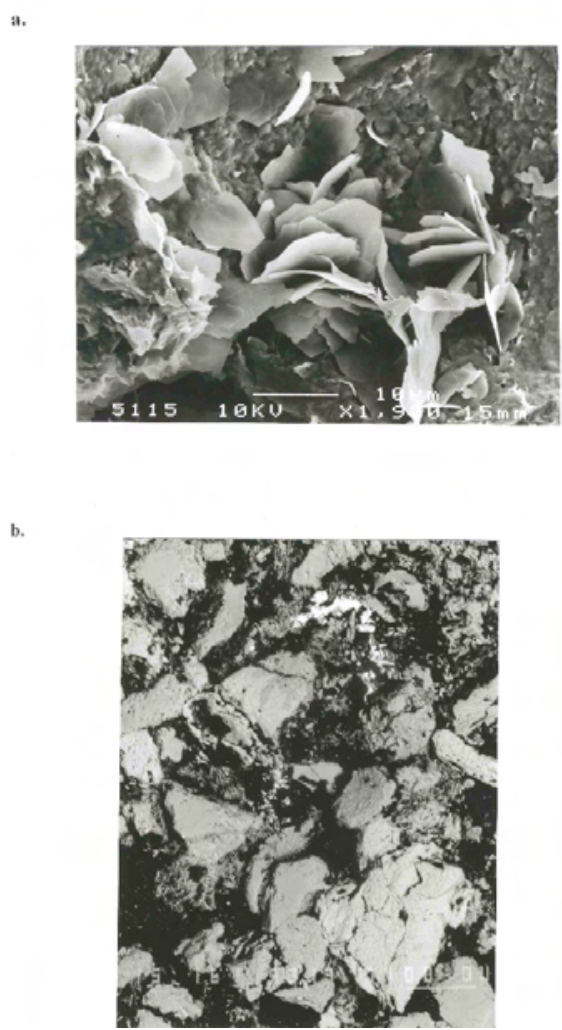

Figure 7. SEM photomicrograph showing (a) chlorite, Adigrat sandstone formation, (scale bar 10 micron) (b) secondary porosity generation by dissolution of carbonate cement, Adigrat sandstone formation, (scale bar 1000 micron).

Bull. Chem. Soc. Ethiop. 2008, 22(1) 
The porosity value in the Adigrat sandstone formation ranges from 0.1 (in tightly compacted and clay cemented areas) to $20.4 \%$ (in areas where secondary porosity generated by dissolution of carbonate) (Table 1; Figure 7b). Primary porosity is preserved in silica-cemented sandstones due to framework grains stability. Permeability ranges from 1 $\mathrm{mD}$ (tightly compacted and clay cemented areas) to $710 \mathrm{mD}$ (in areas where secondary porosity generated by dissolution of carbonate).

\section{BACKGROUND GEOLOGY OF THE ULSTER BASIN, UK}

The basin was in-filled with 10,000 meters thick rudaceous, arenaceous, argillaceous, carbonate and evaporite deposits. Pre-Carboniferous, Lower Carboniferous, Upper Carboniferous, PermoTriassic and Post-Triassic rocks are the dominant rock types in the Ulster Basin (Figure 8). The general chrono-lithostratigraphy of the Ulster Basin is given in Figure 9. The basin underwent multiple phases of uplift and erosion in the Upper Jurassic and Mid-Cretaceous, and also uplift and inversion in the Upper Tertiary [27, 28].

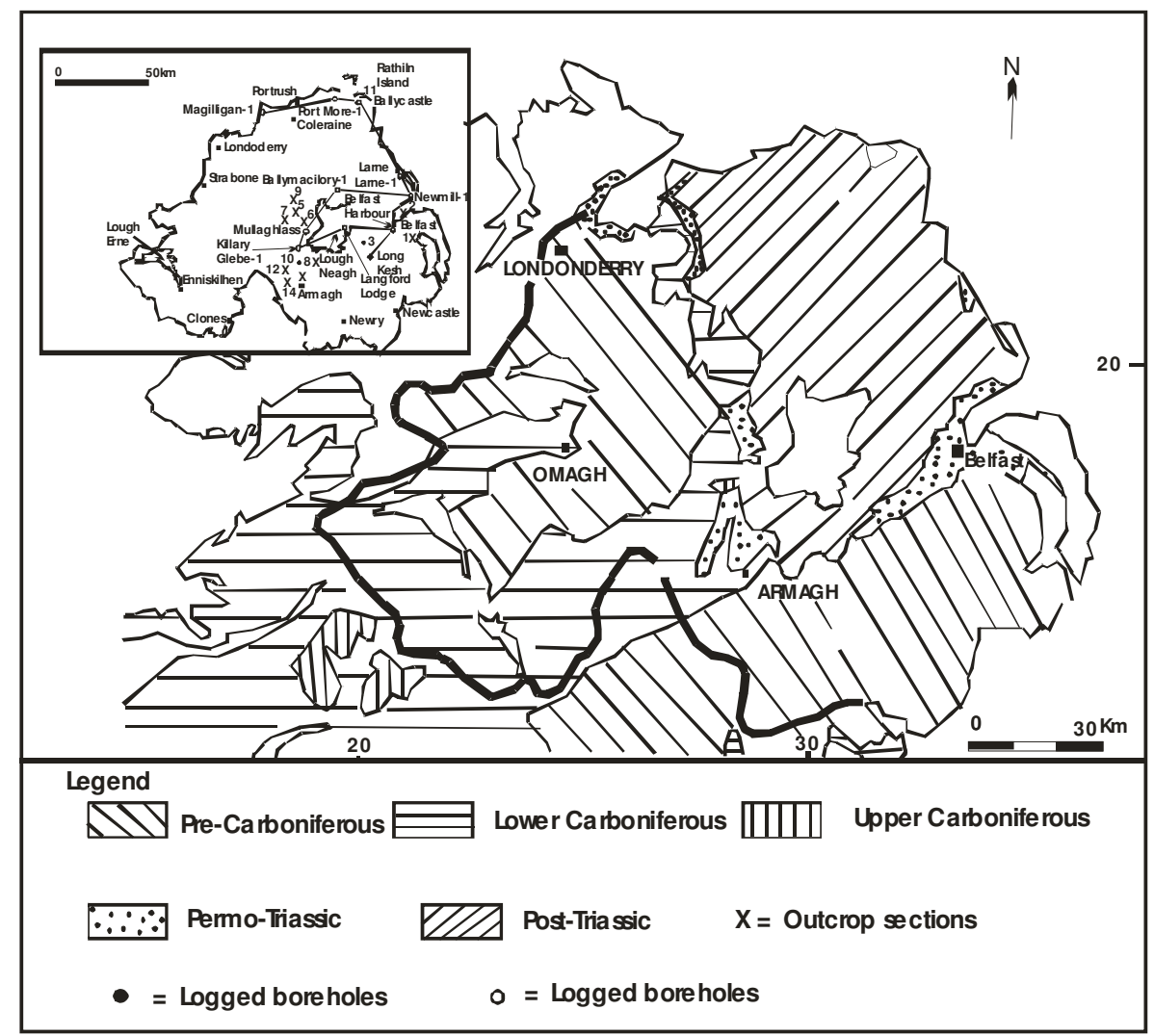

Figure 8. Geological and location map of the Permo-Triassic sandstones, Ulster Basin $(1=$ Scrabo, 2 = Cultra, 3 = borehole $4 \mathrm{~B}, 4=$ Dorlies, $5=$ Draperfield, $6=$ Coalisland, $7=$ Templerreagh borehole, $8=$ Twyford Mill, $9=$ Ballyloughan Bridge, $10=$ Elm Bush, $11=$ Murlough Bay, 12 = Mill Town, 13 = Red Ford $)$. 
The Precambrian rocks (Moinian and Dalradian assemblage) are the oldest and the basement of the Ulster Basin [3, 29]. The Precambrian complex was unconformably overlain by the Ordovician-Silurian sedimentary and igneous rocks. The Devonian old red sandstone unconformably overlies either on the Precambrian basement or the Ordovician-Silurian sedimentary and igneous rocks $[3,29]$. The lower carboniferous limestone and sandstones are widely distributed in south and southwest part of the Ulster Basin (Figure 8). The upper carboniferous is represented by Namurian and Westphalian sediments [29].

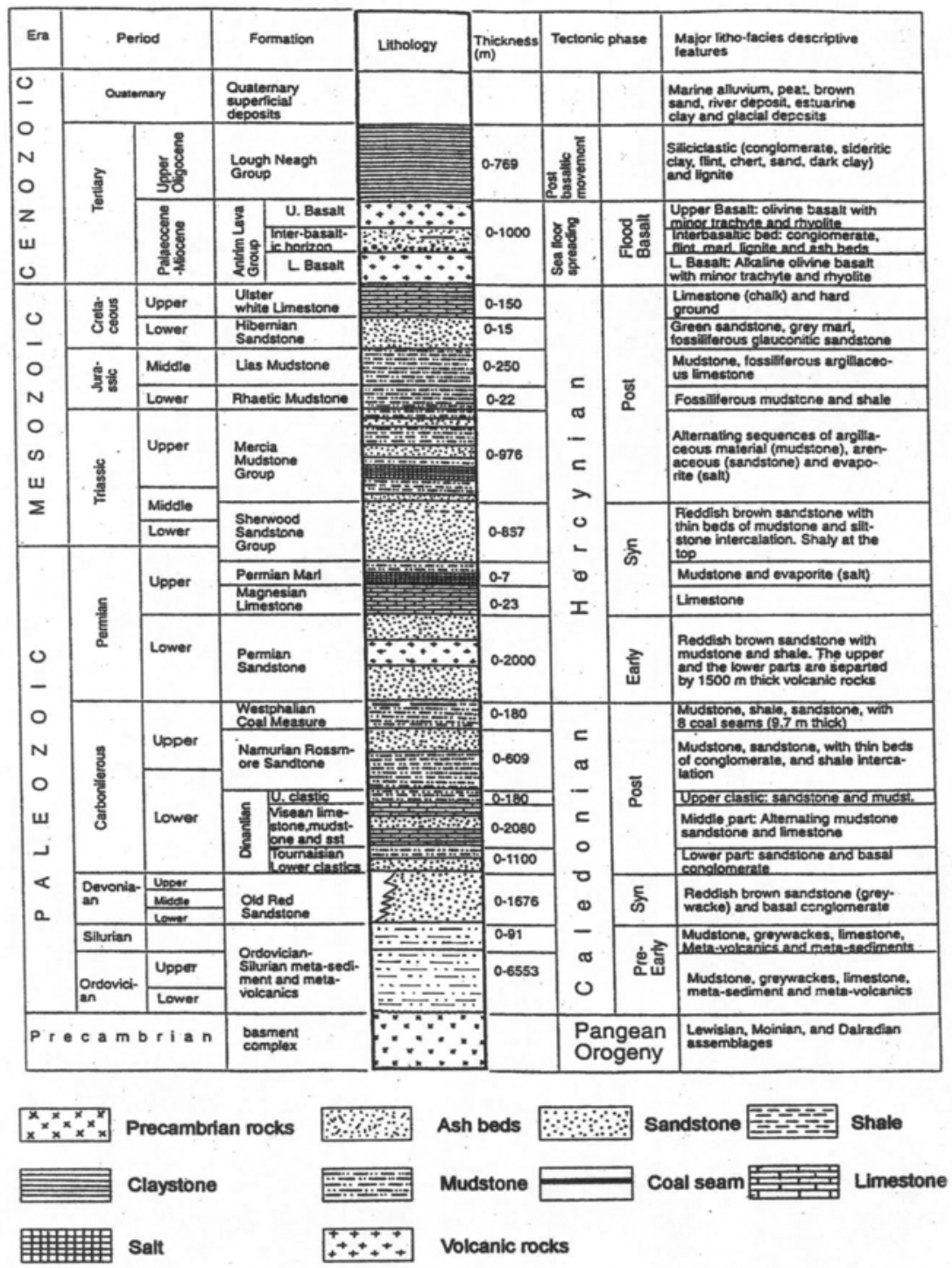

Figure 9. Chrono, litho-stratigraphic section of the Ulster Basin. 
The Permo-Triassic sandstones in the Ulster Basin had been accumulated in rapidly subsiding fault-bounded onshore basins, as has been elsewhere in the British Isles. The PermoTriassic sandstones lie on the Dalradian, the carboniferous and the old red sandstone, and are capped by the Mercia mudstone group [3, 4, 30].

The Permo-Triassic sandstones vertically pass up into $976 \mathrm{~m}$ thick Mercia mudstone group. The Mercia mudstone group is interpreted as a complex arid playa-floodplain-aeolian deposit containing a variety of Mg-rich clays and carbonates [31]. The Mercia mudstone group was overlain by the Rhaetic-Liassic marine mudstones and tertiary volcanics.

\section{RESULTS}

Diagenesis of the Permo-Triassic Sandstones. The reddish-brown, fine to medium-grained, subangular to rounded, moderately to well-sorted sandstones are typical of red bed sedimentation. Framework components include: quartz (79\%), feldspar (13.8\%), rock fragments (1.8\%), mica $(2.2 \%)$, and heavy and opaque minerals $(2 \%)$. The mean ratio of quartz, feldspar and lithic fragments (QFL) is 86.8:11.9:1.3, and are cemented by carbonate and clay minerals (Table 2).

Table 2. Framwork grains, cementing minerals and porosity of the Permo-Triassic sandstones, Ulster Basin.

\begin{tabular}{|c|c|c|c|c|c|c|c|c|c|c|c|c|}
\hline \multirow[t]{2}{*}{ Locality } & \multirow[t]{2}{*}{ Sample No } & \multirow{2}{*}{$\begin{array}{c}\text { Depth in } \\
\text { meter }\end{array}$} & \multirow{2}{*}{\begin{tabular}{|l|} 
Cem- \\
ent \\
type
\end{tabular}} & \multicolumn{3}{|c|}{ Framework grains } & \multirow[b]{2}{*}{ Mica } & \multirow[b]{2}{*}{$\begin{array}{l}\text { Opa- } \\
\text { que }\end{array}$} & \multicolumn{3}{|c|}{ Cementing minerals } & \multirow[b]{2}{*}{$\begin{array}{l}\text { Poro- } \\
\text { sity }\end{array}$} \\
\hline & & & & Quartz & $\begin{array}{l}\text { Feld- } \\
\text { spar }\end{array}$ & $\begin{array}{l}\text { Rock } \\
\text { frag- } \\
\text { ment }\end{array}$ & & & Clay & $\begin{array}{l}\text { Cal- } \\
\text { cite }\end{array}$ & $\begin{array}{l}\text { Dolo- } \\
\text { mite }\end{array}$ & \\
\hline \multirow[t]{2}{*}{ Scrabo } & NISC-01 & Outcrop & \multirow{7}{*}{ Clay } & 52.8 & 28.8 & & 0.6 & & 16.2 & & & 1.6 \\
\hline & NISC-01 & Outcrop & & 52.6 & 24.8 & 4 & 0.4 & & 7.2 & & & 11 \\
\hline Lagan Valley & NI4B-04 & 102 & & 50.4 & 23.6 & 0.4 & 0.4 & 6.6 & 12.8 & & & 5.8 \\
\hline Draperfield & NIDR-01 & Outcrop & & 62.8 & 22.2 & & 3 & & 12.2 & & & \\
\hline New Mill & BHNM-01 & \begin{tabular}{|l|}
1975.1 \\
\end{tabular} & & 44.6 & 16 & 10.4 & & 14.2 & 14.8 & & & \\
\hline Ballyalton & BHBL-01 & 519.5 & & 52.6 & 5.4 & 10 & & 8.4 & 4.8 & 3 & & 15.8 \\
\hline $\begin{array}{l}\text { Ballyloughan } \\
\text { Bridge }\end{array}$ & BHBB-01 & 540.8 & & 52.2 & 16.2 & & & 3.2 & 28.4 & & & \\
\hline Port More & BHPM-01 & 149.7 & \multirow{9}{*}{$\begin{array}{l}\text { Car- } \\
\text { bo- } \\
\text { nate }\end{array}$} & 57.6 & 9.2 & 0.8 & 1.6 & 1.8 & & 13.2 & 6.6 & 9.2 \\
\hline Port More & BHPM-02 & 1397 & & 53.2 & 6.8 & & 0.6 & 1 & & 17 & 6.8 & 14.6 \\
\hline Mire House & BHNH-01 & 950.4 & & 47.2 & 9.2 & 0.6 & 3.2 & 6.8 & & 1 & 26.8 & 5.2 \\
\hline New Mill & BHNM-01 & 1574.3 & & 49.2 & 5.4 & 7.6 & & 7.6 & & 8.6 & 13.2 & 8.4 \\
\hline \multirow[t]{2}{*}{ Lagan Valley } & BH4B-01 & 18 & & 43.4 & 9.6 & 0.4 & 5.2 & 1.2 & & 5 & 10.8 & 24.4 \\
\hline & BH4B-02 & 84 & & 43.4 & 9.4 & 0.4 & 1 & 5.4 & & 5.8 & 10 & 24.6 \\
\hline \multirow{2}{*}{ Cultra } & NICU-02 & Outcrop & & 50.6 & 9.2 & 1 & 0.4 & 2.2 & & 20 & 6 & 10.6 \\
\hline & NICU-04 & Outcrop & & 54.6 & 4.4 & & 0.4 & 22.2 & & 0.4 & & 8 \\
\hline $\begin{array}{l}\text { Mourlough } \\
\text { Bay }\end{array}$ & NIMB-03 & Outcrop & & 63.4 & 0.4 & & & 29.6 & & & & 6.6 \\
\hline
\end{tabular}

The precipitation of authigenic minerals and mineral transformation was controlled by physicochemical conditions (temperature, geothermal gradient, burial depth, initial mineralogical composition) [1,2]. Depositional environment and tectonic setting are the two main factors, which controlled the diagenetic trend of the Permo-Triassic sandstones.

Case studies show the same range of authigenic minerals, with minor differences, in the Permo-Triassic sandstones across Northwestern Europe [3, 4, 13, 26, 28]. The Permo-Triassic sandstones are dominated by alluvial fan, fluviatile, playa and Aeolian depositional environments. The burial depth of the Permo-Triassic Sandstone in the Ulster Basin ranges 
between less than $1 / 2 \mathrm{~km}$ in the shallow (marginal) area and $3 \mathrm{~km}$ in the basin center [3, 4]. Rocks at the basin margins may have experienced a more complex history of fluid-rock interaction than the deeper part of the basins. During burial, fluid expulsion occurred outwards toward the basin margins. The marginal areas of the basin may also be very susceptible to subsequent meteoric groundwater invasion.

The Permo-Triassic sandstones experienced multiple phases of dissolution, replacement, precipitation and recrystallization. The authigenic mineral associations of the Permo-Triassic sandstones reflect continental red bed diagenesis. The Permo-Triassic sandstones have had complex diagenetic history. The most common pore-filling minerals are: (1) concretionary carbonate and anhydrite, (2) grain coating illite-smectite and/or hematite, (3) pore-filling illitesmectite and smectite-chlorite, (4) feldspar overgrowths, (5) quartz overgrowths, (6) poikilotopic calcite, dolomite and anhydrite, (7) kaolinite, (8) actinolite, (9) chlorite, and (10) late-stage hematite cement (for detail diagenesis see [3]; Figure 10). Mechanically infiltrated clay, albite and laumontite cementation are also identified in the Permo-Triassic sandstones. Samples taken from the abandoned Scrabo Hill Quarry and borehole 4B (Lagan Valley) confirmed the presence of actinolite cement possibly related to volcanic and hydrothermal activity. Studies of sandstones at Cultra near the basaltic dykes indicate the presence of porefilling chlorite. The pore-filling chlorite might have favoured by magnesium and iron ions released from the volcanic activity. Authigenic clay minerals abundance in the Permo-Triassic sandstones, in their decreasing order, includes illite-smectite, smectite, illite, smectite-chlorite, kaolinite and chlorite.

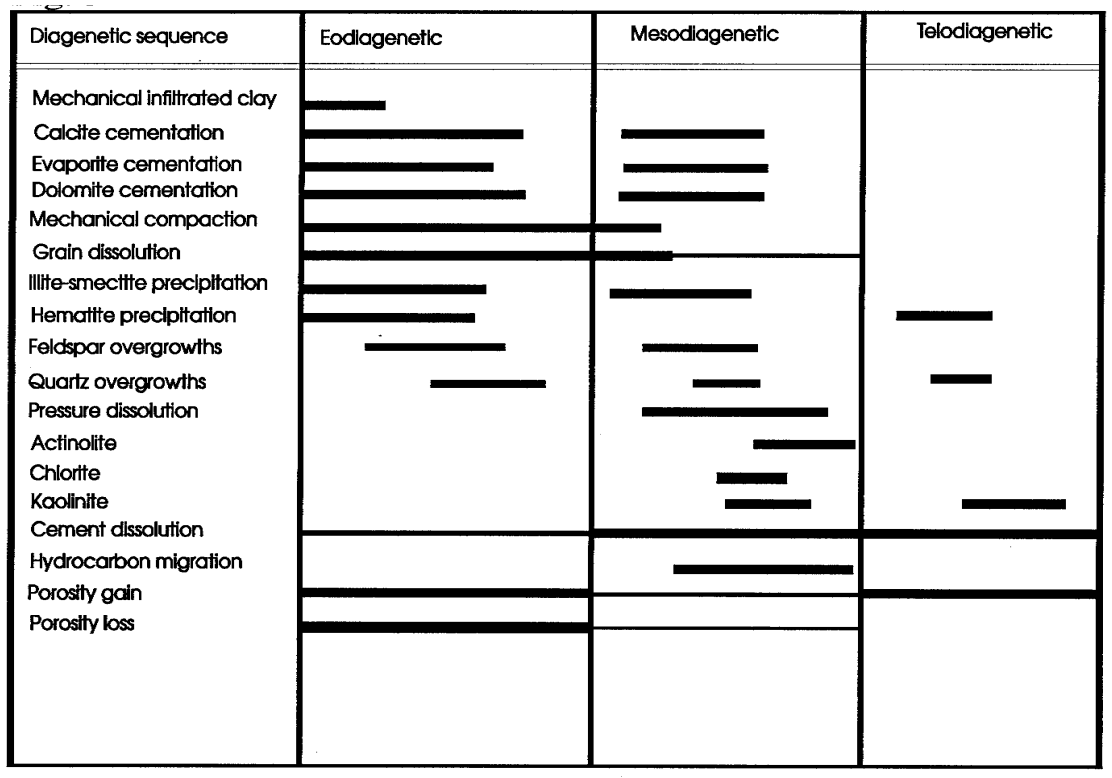

Figure 10. Diagenetic sequences of the Permo-Triassic sandstones, Ulster Basin.

The pore water chemistry from early to late diagenesis is characterised by the following sequences (1) highly alkaline pore water initiated the precipitation of anhydrite, calcrete, dolocrete, and mechanically infiltrated clays, (2) infux of acidic water facilitated dissolution of unstable ferromagnesian minerals and feldspar grains, (3) $\mathrm{pH}$ increased and caused precipitation 
of grain coating illite-smectite and/or hematite, pore-filling feldspar overgrowths, quartz overgrowths, and carbonate cements, (4) percolation of acidic pore water initiated the dissolution of carbonate cements and unstable grains, (5) the reaction between acidic pore water and rock forming minerals increased the $\mathrm{pH}$, and as the result smectite, illite-smectite, smectitechlorite, and actinolite precipitation took place, and (6) further percolation of acidic water and dissolution of unstable grains facilitated the precipitation of kaolinite during the early tertiary uplift and inversion of sandstone bodies.

The following diagenetic clay minerals are identified in the Permo-Triassic sandstones:

(a) Mechanically infiltrated clay. Minor amounts of infiltrated clay are identified as earliest diagenetic stages in some of the studied samples (Figure 11a), and account up to $2 \%$. The noncrystalline form of infiltrated clays indicates a detrital origin. Study of deep borehole showed the absence of infiltrated clay at depth, probably due to conversion to authgenic clay minerals.

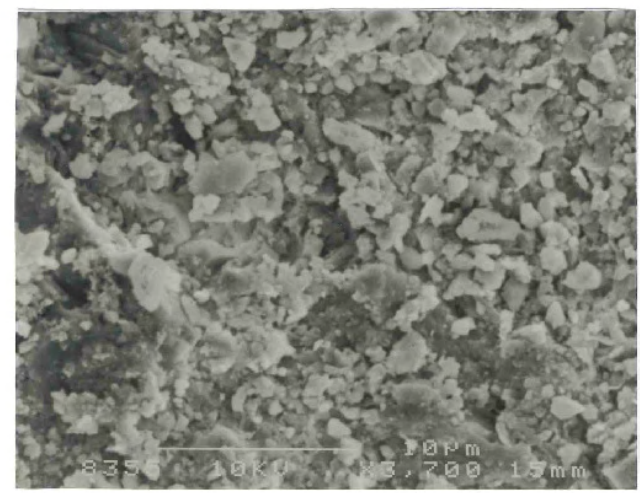

b.

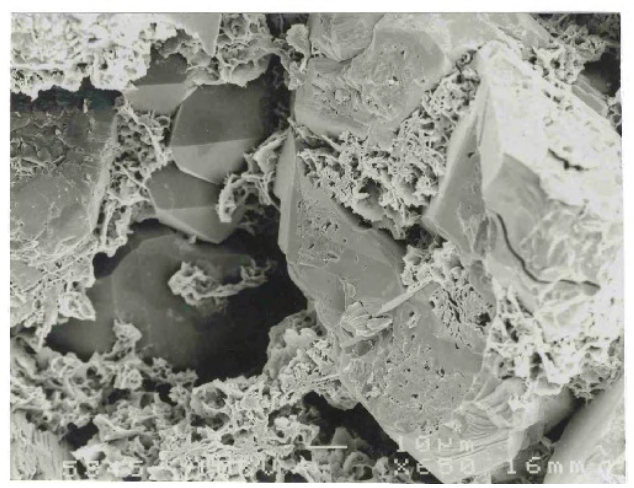

Figure 11. SEM photomicrograph showing (a) infiltrated clay, Permo-Triassic sandstones (scale bar 10 micron) and (b) grain coating smectite, Permo-Triassic sandstones (scale bar 10 micron). 


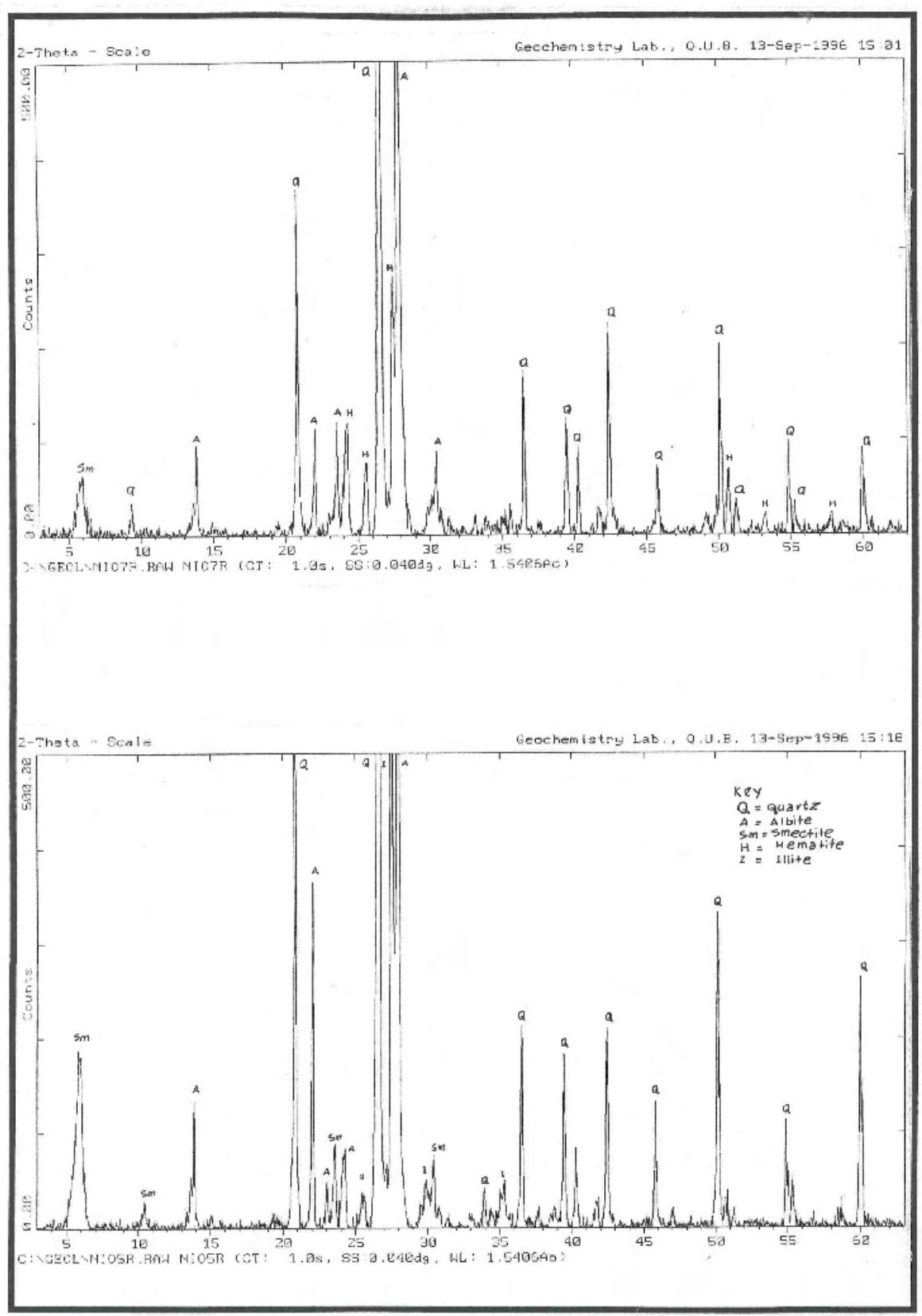

Figure 12. XRD results of the Permo-Triassic sandstones.

Bull. Chem. Soc. Ethiop. 2008, 22(1) 
(b) Grain-coating clay minerals. The dissolution and/or alteration of unstable ferromagnesian minerals and feldspar grains by acidic pore water liberated or released hydrated and anhydrated ions of potassium, sodium, calcium, aluminium, magnesium, silicon and iron into the diagenetic environment. The breakdown of the unstable minerals resulted in the precipitation of authigenic clay minerals.

Thin section, SEM and probe analysis showed the presence of grain coating smectite, illitesmectite and illite (Figures 11b, 12a and b). Volumetrically, illite-smectite and smectite are the most abundant grain-coating clay minerals in the Permo-Triassic sandstones. Grain coating illite-smectite and smectite are the earliest authigenic minerals. They are well developed around the detrital grains as partial and complete grain coating (Figures 11b). Smectite in the studied samples is characterized by either platy or wispy edges ranging from 2 to $10 \mu \mathrm{m}$ thick. Illitesmectite pairs are 5-15 $\mu \mathrm{m}$ in length and 1-2 $\mu \mathrm{m}$ in width, rooted on the edge of detrital grains. SEM studies revealed minor amounts of grain coating chlorite in the form of individual plates with a honeycombed morphology ranging from 2 to $10 \mu \mathrm{m}$ in diameter.

a.

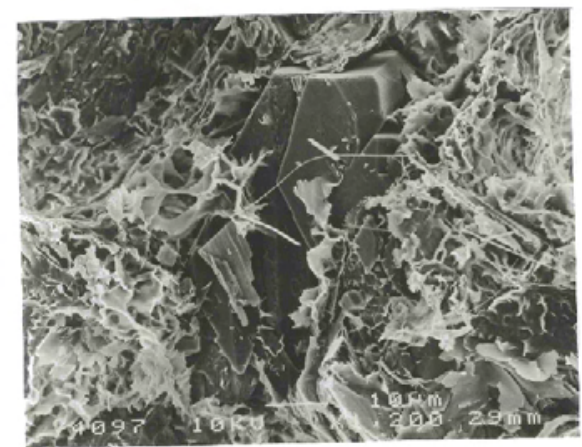

b.

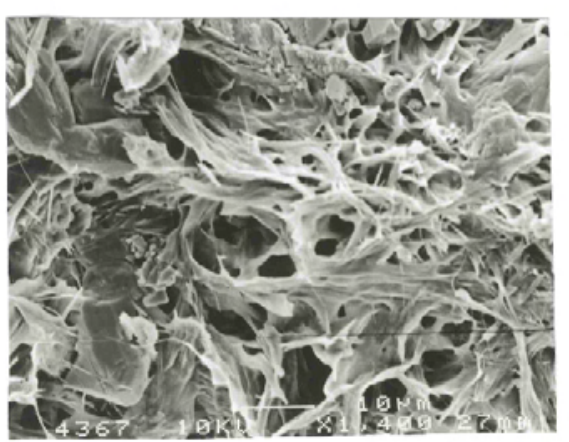

Figure 13. SEM photomicrograph showing (a) grain coating illite-smectite, Permo-Triassic sandstones (scale bar 10 micron), (b) pore-filling smectite, Permo-Triassic sandstones, (scale bar 10 micron).

(c) Pore-filling clay minerals. The late-stage smectite and illite-smectite precipitated as intergranular pore-filling cement. The dissolution of detrital feldspars and ferromagnesian 
minerals was the main source of ions for the authigenesis of smectite and illite-smectite. Pore-filling illite-smectite is the most abundant and occurs as bridge between grains, with a cellular or boxwork structure (2 to $15 \mu \mathrm{m}$ thick) (Figure 13b). Smectite has a platy-hairy termination also with cellular and boxwork texture. Illite-smectite and smectite play major role in reducing the permeability of the Permo-Triassic sandstones.

a.
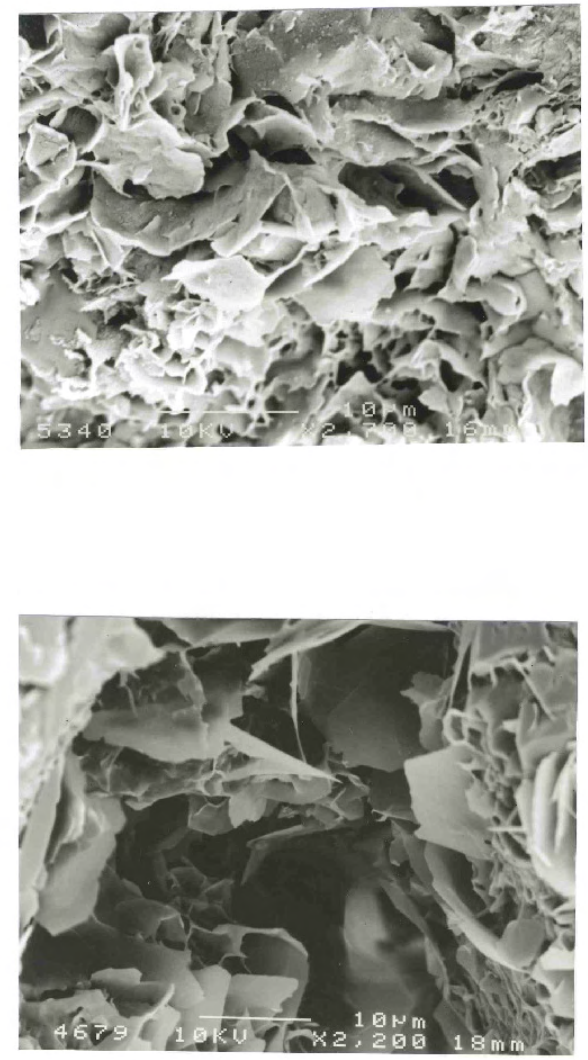

Figure 14. SEM photomicrograph showing (a) pore-filling smectite-chlorite, Permo-Triassic sandstones (scale bar 10 micron), (b) pore-filling chlorite, Permo-Triassic sandstones (scale bar 10 micron).

Smectite-chlorite and chlorite are also identified as late-stage pore-filling clay minerals by SEM studies (Figure 14a and b). Chlorite is found in the form of individual plates and cabbage head-like morphotypes. Smectite-chlorite exists in the form of box-work to rosette morphotypes. Most chlorite is associated with smectite and smectite-chlorite. Core samples confirmed the presence of chlorite cements in deep burial. The dissolution of carbonate cements and unstable grains, volcanic and hydrothermal activities might have instigated precipitation of chlorite during the late diagenetic environment $[4,32]$.

Illite is another late diagenetic pore-filling clay mineral. Illite is less abundant than to illitesmectite and smectite. It is characterized by platy and hairy termination. SEM studies show that 
illite is closely associated with altered feldspar grains and kaolinite (Figure 13a). Fibrous illite projections are noted on box-work smectite near the volcanic intrusions and deeper burial.

(d) Kaolinite precipitation. Kaolinite precipitation was initiated in the mesodiagenetic regime. Uplift and inversion caused further dissolution unstable grains and to precipitate kaolinite in the telodiagenetic regime. The introduction of acidic pore water initiated dissolution of K-feldspar or alteration of mica that might have provided the necessary ions for the precipitation of kaolinite.

\section{DISCUSSION}

The Permo-Triassic sandstones in the Ulster Basin consist of quartz arenites, sub-arkosic and arkosic arenites, possibly reflecting source area geology. The acidity of the Permo-Triassic climate might have initiated alteration in the source terrains. Feldspar grains in all sandstones exhibit multiple types of alteration (kaolinization, illitization, albitization and laumontitzation). Dissolution was initiated immediately after deposition. The basin experienced multiple phases of meteoric water invasion. Circulating acidic meteoric pore water caused dissolution of feldspar and ferromagnesian minerals and produced clay minerals.

Eodiagenesis. The eodiagenetic regime is influenced by the surface depositional environment prior to effective burial, such as surface interstitial pore water, redox potential (Eh), acidityalkalinity $(\mathrm{pH})$ conditions, and activities of dissolved ionic species [4, 33, 34]. Mechanically infiltrated clay was introduced by an influx of meteoric water into the depositional environment $[35,36]$. The infiltrated clay minerals settled out of suspension from mud-laden water in contact with impermeable layers, and lie tangential to the grain surfaces rather than perpendicular to the grain surfaces [37]. The non-crystalline form indicates their detrital origin. The low abundance of mechanically infiltrated clay is due to either the masking effect by late-stage authigenic clay minerals or alteration to authigenic clay minerals.

Acidic pore water facilitated the dissolution of unstable grains (ferromagnesian and feldspar) and released ions into the pore water. The ions liberated from the unstable grains (potassium, sodium, calcium, aluminium, silicon, magnesium and iron), are the main sources for the precipitation of numerous clay minerals in the diagenetic environment. Grain-coating illitesmectite is either directly precipitated from pore water or a replacement of K-feldspar and ferromagnesian minerals or both. Clay replacing K-feldspar tends to be illite, whilst clay replacing basic ferromagensian minerals exhibits a chemistry of smectite and/or chlorite $[13,18$, 34]. Authigenic grain coating illite-smectite is differentiated from infiltrated clay by their hairy termination, box-work or honeycombed texture. The idiomorphic illite-smectite platelets are attached perpendicular to framework grain surfaces and arranged in a face-to-edge or edge-toedge cellular pattern indicating their authigenic origin $[18,37]$.

Mesodiagenesis. Depending upon the various types of ions and pore water circulation through the sand bodies, different types of authigenic minerals precipitated in the mesodiagenetic environment. It is a regime after effective burial depth in which the solubility of minerals increase, reaction rates increase and reaction barriers are more easily overcome [33, 34].

Further leaching of ferromagnesian minerals and feldspar grains introduces potassium, aluminium, calcium, magnesium, silicon and iron ions into the pore water, and accounts for further authigenesis of pore-filling illite-smectite, smectite-chlorite, illite and chlorite in the diagenetic environment. Mechanically compacted mudstone and siltstone of the Mercia mudstone group expelled large volume of mineralised pore water, which migrated into the Permo-Triassic sandstones. The free movement of the formation water along the bedding planes helped to expel mineralised water from the silty, muddy and shaly facies into the sandstone-rich 
section of the basin $[31,32]$. In hot arid and semi-arid climates where evaporation is greater than precipitation, high $\mathrm{pH}$, high retention of $\mathrm{Mg}^{2+}, \mathrm{Ca}^{2+}$ and $\mathrm{Na}^{+}$and high $\mathrm{Si}: \mathrm{Al}$ ratio favour the authignesis of smectite [38, 39].

Illie-smectite is the most abundant clay mineral in the Permo-Triassic sandstones. Illitesmectite cements are common in the Permo-Triassic sandstones across the British Isles and NW Europe [3, 4, 26, 34, 40, 41]. The abundance of illite in the studied samples reflects the transformation of smectite and illite-smectite into illite. Illitization of smectite might have been favoured by potassium-rich alkaline pore water. The crystallization of smectite to illite liberated silicon, calcium, magnesium and iron [42]. The dissolution of K-feldspar might have provided the necessary $\mathrm{K}^{+}$ion to promote illitization. Illite can also be precipitated from potassium, aluminium and silicon supersaturated pore water [43]. The necessary potassium, aluminium and silicon ions for the authigenesis of illite are possibily derived from the Dalradian granite and granodiorite. Following deposition of the Permo-Triassic sandstones in the British Isles it underwent continuous burial until the Cimmerian Uplift [28, 34, 44]. Illitization of smectite is believed to have occurred after the Cimmerian Uplift. The burial history curve of the PermoTriassic sandstones involves a depth of nearly $3 \mathrm{~km}$ after the Cimmerian Uplift [4]. Considering a geothermal gradient of $30{ }^{\circ} \mathrm{C} / \mathrm{km}[34]$, the sediment reached a temperature of nearly $90{ }^{\circ} \mathrm{C}$, which initiated the conversion of smectite and mixed-layer illite-smectite into illite. Smectite and illite-smectite become unstable between 60 and $100{ }^{\circ} \mathrm{C}$, when they will be transformed into illite [32].

Chlorite authignesis need alkaline pore water with little potassium, but sufficient magnesium ions $[18,45]$. The late-stage intergranular pore-filling chlorite directly precipitated from silicon, aluminium, magnesium, and iron-rich pore water, possibly favoured by transformation of smectite to illite. Chloritization possibly took place at $220( \pm 25){ }^{\circ} \mathrm{C}$ near the basaltic intrusions [46]. The presence of chlorite in the Cultra samples is related to the Tertiary diabasic sills and dikes that intruded the Permo-Triassic sandstones. The magnesium and iron for the authignesis of chlorite possibly derived from volcanic intrusions and hydrothermal fluids [32].

Clay minerals effect on reservoir characteristics. The porosity and permeability of the studied sandstones was reduced by intergranular pore-filling illite-smectite, smectite, illite, smectitechlorite, kaolinite and chlorite (Figures 11a and b, 13a and b, 14a and b). Porosity of clay cemented areas reaches up to $15.8 \%$ (Table 2). Pore-bridging smectite had the highest effect on porosity and permeability. Pore-lining and pore-filling illite-smectite has an important effect in reducing porosity and permeability of the Permo-Triassic sandstones in the Ulster Basin. The illite-smectite occurred as pore bridging, and increased the specific surface area and tortousity, leading to very high pore-to-throat size ratio, causing drastic lowering of permeability [45]. Smectite cementation obliterated porosity and permeability by forming complex pore bridges. Box-work to rostte smectite-chlorite had the highest effect in reservoir characteristics by blocking the pore-throat. Smectite-chlorite in-filled pores either not filled with oil or oil will not produced from such pores. The platy illite also caused significant porosity and permeability reduction, whilst illite with hairy terminations has a lesser effect on permeability characteristics [47]. The permeability of illite-cemented sandstone did not exceed $1 \mathrm{mD}$ even in samples with porosities above $10 \%$ [26]. Extensive illite-smectite cementation reduced both porosity and permeability to zero. Kaolinite precipitation also to some extent accounted for the reduction of porosity and permeability.

In the late stage diagenesis, dissolution of carbonate cements and unstable grains facilitated secondary porosity generation. Most of the secondary porosity generated during mesodiagenesis, but minor amounts of secondary porosity also generated in telodiagenesis due to uplifting in Tertiary [48]. The porosity ranges from 0.1 (tightly compacted and/or clay cemented areas) to 27 $\%$ (in areas where secondary porosity generated by the dissolution of carbonate cements). 
The permeability of the studied sandstones ranges from $2 \mathrm{mD}$ (tightly compacted and/or clay cemented areas) to $1350 \mathrm{mD}$ (in areas secondary porosity generated by the dissolution of carbonate cements) (Figure 15). Dissolution of carbonate cemented areas by acidic pore water in the fine to medium-grained sandstones create good reservoirs for oil and gas accumulation, whereas clay-cemented sandstones have very poor reservoirs quality.

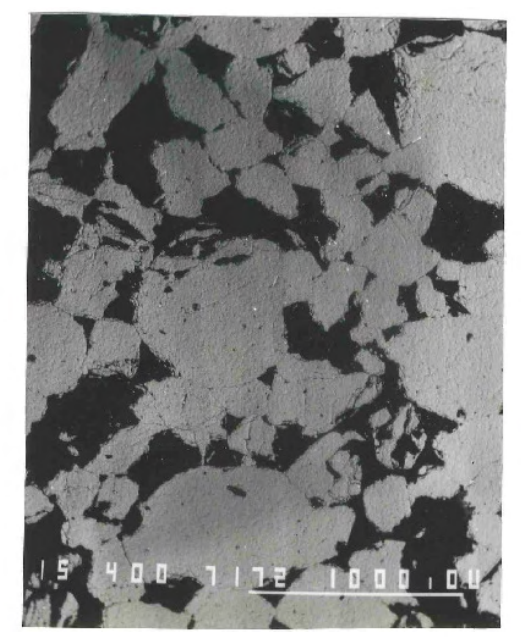

Figure 15. Microprobe photomicrograph showing secondary porosity generation by dissolution of carbonate cements (scale bar 1000 micron).

\section{CONCLUSIONS}

(1) The Adigrat sandstone formation is characterized by fine to coarse-grained, moderately to well-sorted, sub-mature to mature quartz and sub-arkosic arenites. Diagenetic evolution, porosity and permeability characteristics of the Adigrat sandstone formation is controlled by the source area geology, depositional environments, climates, pore water chemistry and circulation, burial and thermal history of the basin.

(2) Influx of acidic meteoric pore water facilitated acidic environment to leach out unstable grains to release ions into the diagenetic environments. As the $\mathrm{pH}$ increased precipitation of grain-coating illite took place at early-stage of diagenesis. In the late-stage of diagenesis, acidic pore water reacted with carbonate cements to generate secondary porosity. As the $\mathrm{pH}$ value increased precipitation of pore-filling kaolinite, illite and chlorite took place in the Adigrat sandstone formation.

(3) The porosity of the Adigrat sandstone formation reduced by phylosilicates, silica hematite and carbonate cements. Clay cementation has the worst effect in reducing porosity, permeability and other reservoir characteristics. Porosity reduced by clay minerals are irreversible, whereas porosity reduced by carbonate minerals are reversible due the dissolution by acidic pore water to generate secondary porosity.

(4) The Adigrat sandstone formation has porosity and permeability up to $20.4 \%$ and $710 \mathrm{mD}$, respectively. The coarse to medium-grained sandstone facies is the most porous and permeable, and potential reservoir for oil and gas accumulation. 
(5) Authigenic clay minerals abundance in the Adigrat sandstone formation include: kaolinite > illite $>$ chlorite. Kaolinite reduced porosity. Kaolinite in-filled pores either not filled with oil or oil can not be produced from such pores. Illite and chlorite also reduced the porosity of the Adigrat sandstone formation and oil will not produced from such pores. The study showed that sandstone cemented by illite with porosity above $15 \%$, the permeability not exceeds $3 \mathrm{mD}$. Chlorite is less abundant, but has the highest effect in destroying the reservoir characteristics.

(6) The Permo-Triassic sandstones in the Ulster Basin is characterized by fine to mediumgrained, sub-angular to sub-rounded, moderately sorted arkosic and sub-arkosic arenites. The most common pore-filling minerals are: grain coating illite-smectite and/or hematite, smectite, illite-smectite, illite, smectite-chlorite, chlorite and kaolinite. Studies of sandstones near the basaltic dykes indicate the presence of pore-filling chlorite.

(7) Infiltrated clay are identified as earliest diagenetic stages in some of the studied PermoTriassic sandstones samples, and account up to $2 \%$. The non-crystalline form of infiltrated clays indicates a detrital origin. Study of deep borehole showed the absence of infiltrated clay at depth, probably due to conversion to authgenic clay minerals.

(8) Illite-smectite and smectite are extensively distributed in Permo-Triassic sandstones in the Ulster Basin, and associated with all types of other cements. They exist as (1) grain coating mineral, (2) pore-lining cement and (3) pore-filling cement. They are associated with feldspar and quartz crystals, rhombs of calcite and dolomite cements. Illite-smectite cement is also closely associated with illite and chlorite. Clay minerals abundance is illite-smectite $>$ smectite $>$ illite $>$ smectite-chlorite $>$ kaolinite $>$ chlorite.

(9) The pore water chemistry for the precipitation of clay minerals from early to late diagenesis in the Permo-Triassic sandstones is characterized by the following sequences (1) gravity-driven acidic meteoric pore water facilitated dissolution of unstable ferromagnesian minerals and feldspar grains. As the $\mathrm{pH}$ increased precipitation of grain coating illite-smectite and/or hematite took place. (2) In the late-stage diagenesis, acidic pore water initiated the dissolution of carbonate cements and unstable grains to create secondary porosity. (3) The reaction between pore water and rock forming minerals increased the $\mathrm{pH}$. As the alkalinity increased pore-filling, illite-smectite, smectite-chlorite, illite and chlorite precipitation took place. (4) In the early tertiary, uplift and inversion of the sandstone bodies favoured the percolation of acidic meteoric water, which caused further dissolution of feldspars and precipitation kaolinite.

(10) The reservoir quality of the Permo-Triassic sandstones in the Ulster Basin is highly variable. It ranges from marginal to good. The fine to medium-grained sandstones are the most porous and permeable facies of the studied samples. The maximum porosity and permeability values recorded in areas where secondary porosity is generated by dissolution of carbonate cements. The porosity and permeability reaches a maximum of $27.4 \%$ and $1350 \mathrm{mD}$, respectively. The porosity drops to $0.1 \%$ and permeability to $2 \mathrm{mD}$ in areas of clay-cemented sanstones. The reservoir quality strongly reduced in clay cemented areas. The percolation of acidic pore waters in the clay-cemented areas did not improve the reservoir quality of the Permo-Triassic sandstones.

(11) The types of clay minerals formed in the Adigrat sandstone formation are different from the Permo-Triassic sandstones in the Ulster Basin. This variation commonly depends upon the source area geology, climate and depositional environments. The Adigrat sandstone formation deposited in alluvial fan and fluviatile depositional environments in arid and humid climate, whereas the Permo-Triassic sandstones were deposited in alluvial fan, fluviatile, aeolian and playa depositional environments in arid and semi-arid climates. The main sources for the sedimentation of the Adigrat sandstone formation were granite, quartzite, biotite and hornbled gneiss, whereas the Permo-Triassic sandstone sources are dominated by quartzite, granodiorte, basic igneous complex and schistose rocks. 


\section{AKNOWLEDGEMENTS}

The original manuscript was read by Dr. J. Parnell and his comments are gratefully acknowledged. Thanks are also extended to Dr. E. Gierlowski-Kordesch, and Dr. A. Ruffell. Sampling of boreholes cores was made possible through kind permission of the Geological Survey of Northern Ireland, UK. Most of the laboratory studies were carried out at Geochemical Laboratory and Electron Microscopy Unit, Queen's University of Belfast, Northern Ireland. The staffs of these institutions are acknowledged for their support and help. This study was financially supported by the Ministry of Mines and Energy, Ethiopia and School of Geosciences, Queen's University of Belfast, UK.

\section{REFERENCES}

1. Bjorlykke, K. Diagenesis I, Development in Sedimentology, Chilingarian, G.V.; Wolf, K.H. (Eds.), Elsevier: Amsterdam; 1988; pp 555-588.

2. Helmold, K.P.; Van de Kamp, P.C. Clastic Diagenesis, McDonald, D.A.; Surdum, R.C. (Eds.), AAPG Mem. 37, American Association of Petroleum Geologists: Oklahoma, USA; 1984; pp 239-276.

3. Ahmed, W. Ph.D. Thesis, The Queen's University of Belfast, Belfast; UK; 1997; p 238.

4. Parnell, J. Jour. Petrol Geol. 1992, 15, 51.

5. Hunegnaw, A.; Sage, L.; Gonnard, R. Jour. Petrol Geol. 1998, 21, 401.

6. Russo, A.; Assefa, G.; Atnafu, B. Neues Jahrbuch Geologie Palaontologie Monatshefte 1994, 5, 291.

7. Raaben, V.P.; Komenyev, S.P.; Lissin, V.N.; Kitachew, W.T. Preliminary Report on the Ogaden Basin, Ethiopia, Ethiopian Institute of Geological Surveys: Addis Ababa; 1979; Note No. 112.

8. Bosellini, A. American Association of Petroleum Geologists Memoir 1992, 53, 185.

9. Getaneh, A. Geosci. J. 1981, 2, 63.

10. Getaneh, A. N. Jb. Geol. Palaont. Abb. 1991, 182, 255.

11. Serawit, A.; Tamrat, M. The Geology of Gundo-Meskel and Ejere Area, North Shoa, Abay Basin, Petroleum Operations Department: Addis Ababa; 1996.

12. Folk, R.L. Petrology of Sedimentary Rocks, Hemphill Publishing Company: Austin, Texas, 1968, p 182.

13. Bjorlykke, K. Sediment Diagenesis, Vol. 115, Parker A.; Sellwood, B.W. (Eds.), D. Reidel Publishing Company: Dordrech; Holland; 1983; pp 169-213.

14. Giles, M.R.; Marshall, J.D. Marine and Petroleum Geology, 1986, 3, 243.

15. Besly, B.M.; Turner, P. Geol. Soc. Spec. Pub. (London) 1983, 11, 131.

16. Ali, A.D.; Turner, P. J. Sed. Petrol. 1982, 52, 187.

17. Curtis, C.D. Geol. Soc. Spec. Pub. (London) 1983, 12, 113.

18. Weaver, C.E. Clays, Muds and Shales, Elsevier: Amsterdam; 1989.

19. Hurst, A.; Irwin, H. Clay Mineralogy, 1982, 17, 5.

20. Fuchtbauer, H. Proc. $7^{\text {th }}$ World Pet. Congr. Mexico; 1967, 2, 353.

21. Irwin, H.; Hurst, A.R. Geol. Soc. Spec. Pub. (London) 1983, 12, 127.

22. Loucks, R.G.; Douge, M.M.; Galloway, W.E. Importance of secondary leaching porosity in lower tertiary sandstone reservoir along the Gulf Coast, Bur. Econ. Geology, Geol. Circ., Univ. Texas: Texas; 1980, pp 80-102.

23. Loucks, R.G.; Douge, M.M.; Galloway, W.E. Am. Assoc. Petroleum Geologists, Mem. 1984, $37,15$.

24. Parnell, J. Geol. Soc. Spec. Pub. (London) 1987, 36, 297. 
25. Bjorlykke, K. Am. Assoc. Petroleum Geologists, Mem. 1984, 37, 277.

26. Gaupp, R.; Matter, A.; Platt, J.; Ramseyer, K.; Walzebuck, J. Am. Assoc. Petroleum Geologists Bull. 1993, 77, 1111.

27. Coward, M.P. Geol. Soc. Lond. Spec. Pub. 1995, 91, 7.

28. Glennie, K.W.; Boegner, P.L.E. Sole pit inversion tectonics, in: Petroleum Geology of the Continental Shelf of Northwest Europe, Illing, L.V.; Hobson, G.D. (Eds.), Heyden: London; 1981; pp 110-120.

29. Wilson, H.E. Regional Geology of Northern Ireland, Her Majesty's Stationary Office: Belfast ; 1986; p 106.

30. McCaffery, R.J.; McCann, N. Geol. Soc. Lond. Spec. Pub. 1992, 62, 277.

31. Wright, V.P.; Sandler, A.A. J. Geol. Soc. London 1994, 151, 897.

32. Ahmed, W. Bull. Chem. Soc. Ethiop. 2002, 16, 37.

33. Schmidt, V.; McDonald, D.A. Soc. Econ. Paleon. Mineral. Spec. Pub. 1979, 26, 175.

34. Burley, S.D. Clay Minerals 1984, 19, 403.

35. Walker, T.R.; Diagenetic origin of contental red beds in: The Contental Permian in Central, West and South Europe, Falke, H. (Ed.), Reidel: Dordrecht-Holland; 1976; pp 240-282.

36. Mores, M.A.; De Ros., L. Jour. Sed. Petrology 1990, 60, 809.

37. Waught, B. J. Geol. Soc. London 1978, 135, 51.

38. Lewis, D.W.; McConchie, D. Practical Sedimentology, Chapman and Hall: London; 1994; p 213.

39. Boles, J.R. Am. J. Sc. 1982, 282, 165.

40. McKeever, P.A. Geol. Soc. Spec. Pub. (London) 1992, 62, 71.

41. Strong, G.E.; Milodowski, A.E.; Pearce, J.M.; Kemp, S.J.; Prior, S.V.; Morton, A.C. Proceedings of the Yorkshire Geological Society 1994, 50, 77.

42. Hower, J.; Eslinger, E.V.; Hower, M.E.; Perry, E.A. Geol. Soc. Am. Bull. 1976, 87, 725.

43. Macchi, L. Geol. J. 1987, 22, 333.

44. Anderson, T.B.; Parnell, J.; Ruffell, A. Geol. Soc. Spec. Pub. (London) 1995, 91, 103.

45. Tucker, M.E. Sedimentary Petrology and Introduction to the Origin of Sedimentary Rocks, 2nd ed., Blackwell Limited: London; 1996; p 260.

46. Merino, E. J. Sed. Petrol. 1975, 45, 320.

47. Bushell, T.P. Geol. Soc. Spec. Pub. (London) 1986, 23, 189.

48. Parnell, J. Geol. Soc. London Spec. Pub. 2002, 196, 433. 18. 